\title{
The effect of weight on carcass and meat quality of Serra da Estrela and Merino Branco lambs fattened with dehydrated lucerne
}

\author{
José SANTOS-SILVA*, Apolinário VAZ PoRTUGaL \\ Estação Zootécnica Nacional (INIA), Fonte Boa, 2000 Vale de Santarém, Portugal
}

(Received 16 March 2000; accepted 3 April 2001)

\begin{abstract}
Thirty-four ram lambs of the Serra da Estrela (SE) and Merino Branco (MB) breeds were used to evaluate lamb growth performance and the effect of carcass weight on carcass composition and meat quality traits. Five lambs of each breed were slaughtered after weaning, at $16 \mathrm{~kg}$ average live weight $(\mathrm{LW})$, and the remaining were fed ad libitum with dehydrated lucerne and minerals and slaughtered at 25 or $35 \mathrm{~kg} \mathrm{LW}$. The left sides of the carcasses were totally dissected. The Longissimus thoracis and Longissimus lumborum muscles were used for meat quality determination. MB lambs grew faster than SE lambs. The muscle/bone ratio was higher for SE lambs (2.84 vs. 2.63) and breed had no effect on meat quality traits, except for water-holding capacity that was higher for MB lambs. Dressing percentage was about $55 \%$ at weaning, decreased to about $53 \%$ at $25 \mathrm{~kg}$ live weight and remained unchanged afterwards. Muscle/bone ratio increased with slaughter weight, ranging from around 2.5 at weaning to 3.0 at $35 \mathrm{~kg}$ live weight. As carcass weight increased, muscle $\mathrm{pH}$ and water-holding capacity decreased but temperature and intramuscular fat increased. Juiciness scored better for higher carcass weights, however, the overall effect of carcass weight on meat quality traits was minimal, and probably without any commercial impact.
\end{abstract}

lamb / Portuguese sheep breed / growth / carcass quality / meat quality

Résumé - Effet du poids sur la qualité de la carcasse et de la viande d'agneaux Serra da Estrela et Merino Branco, alimentés avec de la luzerne déshydratée. Un essai a été mené sur trente quatre agneaux mâles, de race Serra da Estrela (SE) et Merino Branco (MB), afin d'évaluer la performance de croissance et l'effet de l'augmentation du poids sur la composition de la carcasse et sur la qualité de la viande. Cinq agneaux de chaque race ont été abattus après sevrage, avec un poids vif de $16 \mathrm{~kg}$. Les autres, soumis à une alimentation ad libitum à base de luzerne déshydratée et de minéraux, ont été abattus soit à un poids vif de $25 \mathrm{~kg}$ ou de $35 \mathrm{~kg}$. Après abattage, la demi carcasse gauche de chaque animal a été complètement disséquée. Afin d'évaluer la qualité de la viande, on a utilisé les muscles Longissimus thoracis et Longissimus lumborum. La vitesse de croissance des agneaux MB a été supérieure à celle des agneaux SE. Le rapport muscle/os a été supérieur chez les agneaux SE (2,84 vs. 2,63). La race n'a eu aucun effet sur la qualité de la viande, sauf dans le cas de

* Correspondence and reprints

Tel.: 351243767300; fax: 351243760540; e-mail: ezn.inia@ mail.telepac.pt 
la capacité de rétention d'eau, qui a été supérieure chez les agneaux MB. Le rendement en carcasse, a été de $55 \%$ au sevrage, puis a diminué à $53 \%$ pour un poids vif de $25 \mathrm{~kg}$ et enfin est resté pratiquement constant par la suite. Le rapport muscle/os a augmenté avec le poids de la carcasse ( $\pm 2,5$ au sevrage et 3,0 à $35 \mathrm{~kg}$ de poids vif). L'accroissement du poids a eu un effet significatif sur le $\mathrm{pH}$ et la capacité de rétention d'eau du muscle Longissimus thoracis, qui ont diminué, et sur la température et la graisse intramusculaire, qui ont augmenté. La succulence de la viande a augmenté avec l'accroissement du poids. Cependant les différences sur les caractéristiques sensorielles ont été minimales, et probablement sans aucun effet sur la valeur commerciale.

agneau / race ovine portugaise / croissance / qualité de la carcasse / qualité de la viande

\section{INTRODUCTION}

In Portugal, as in other countries, carcass weight is important for the definition of lamb meat quality and carcass commercial value. Consumer preferences for a specific carcass weight differ from region to region, depending on local breed characteristics as well as traditional culinary and production systems. The lambs of the Serra da Estrela breed (SE), a mountain breed used for milk production, are currently slaughtered at 4-6 weeks of age, producing carcasses of up to $7 \mathrm{~kg}$. Merino Branco (MB), the most widespread national breed, is mainly used for meat production, although many ewes are milked after the weaning of lambs. For this breed, lambs are usually slaughtered after a period of fattening, producing carcasses weighing 10 to $13 \mathrm{~kg}$.

The productivity of sheep meat production systems can be enhanced by increasing the number of lambs produced and/or the slaughter weight, provided meat quality and consumer acceptance are maintained. Sañudo et al. [20] concluded that the carcass weight of Rasa Aragonesa lambs ranging from 8 to $13 \mathrm{~kg}$ had only a minor influence, if any, on sensory properties of meat. Solomon et al. [25] concluded that palatability scores of crossbred lambs slaughtered at 32 or $41 \mathrm{~kg}$ were generally not affected by slaughter weight. Market demands are changing in Portugal and it is now possible to market heavier carcasses, thus allowing more flexibility of the production systems. Furthermore, it is important for producers to determine the growth potential of lambs during fattening and the target slaughter weights. The slaughter weight of MB lambs in intensive production can be increased up to $35 \mathrm{~kg}$ without any detrimental effects on carcass or meat quality [18]. The objective of this trial was to estimate the effect of carcass weight on carcass and meat quality of $\mathrm{SE}$ and MB lambs fed dehydrated lucerne and slaughtered at weaning, 25 or $35 \mathrm{~kg}$ live weight.

\section{MATERIALS AND METHODS}

\subsection{Animals}

Thirty-four ram lambs of the Serra da Estrela $(n=17)$ and Merino Branco $(n=17)$ breeds were reared with their dams and weaned between 42 and 60 days of age. Before weaning, Serra da Estrela lambs were supplemented with concentrate (13 MJ ME $\cdot \mathrm{kg}^{-1}$ dry matter (DM); $18 \%$ crude protein (CP)) while Merino Branco lambs were not. At weaning, five lambs of each breed were slaughtered within a similar weight range and the remaining 12 lambs of each breed were allotted to two groups, to be slaughtered at 25 or $35 \mathrm{~kg}$ body weight. All animals were fed a diet consisting of dehydrated lucerne pellets $(88.9 \%$ DM; $\left.16.9 \% \mathrm{CP} ; 8.5 \mathrm{MJ} \mathrm{ME} \cdot \mathrm{kg}^{-1} \mathrm{DM}\right)$ and minerals (sodium chloride $68.0 \%$; sulphur 
(95\%) 10.0\%; dicalcium phosphate $15.0 \%$; calcium carbonate $5.0 \%$; premix $2.0 \%$ ) ad libitum, until they reached the planned slaughter weights. Lambs were weighed weekly and feed intake of the four groups was measured daily.

\subsection{Slaughter}

Lambs were slaughtered in the Estação Zootécnica Nacional abattoir and hot carcass weight (HCW) and dressing percentage (DP) (hot carcass weight/empty live weight ratio) were determined. During the first $24 \mathrm{~h}$ post mortem, carcasses were kept at room temperature. Temperature and $\mathrm{pH}$ of Longissimus thoracis (LT) muscle were recorded at 1, 3 and $24 \mathrm{~h}$ after slaughter, by using a $\mathrm{pH}$ meter equipped with a penetrating electrode, Hanna Instruments (HI8424). Carcasses were then chilled at $2{ }^{\circ} \mathrm{C}$ for $24 \mathrm{~h}$. After the removal of the kidney and knob channel fat (KKCF), carcasses were split along the spine and the left sides were totally dissected into muscle, subcutaneous and intermuscular fat and bone. Total separable fat (SF) was the sum of subcutaneous and intermuscular fat. The LT and Longissimus lumborum (LL) muscles were excised to assess meat quality. Water-holding capacity (WHC) and dry matter content were determined in fresh samples of the LT muscle, collected at the level of the 12th rib. After removal of the epimysium, the remaining portions of the muscle samples were minced and frozen at $-20{ }^{\circ} \mathrm{C}$, freeze-dried and stored at $4{ }^{\circ} \mathrm{C}$ for further analysis. On the right side of the carcasses, joints containing the LT muscle were collected, vacuum-packed and frozen at $-20{ }^{\circ} \mathrm{C}$ until sensory analysis.

\subsection{Analytical procedures}

The dry matter content of the muscle was determined according to ISO [9]. Waterholding capacity was determined using the modified Grau-Hamm technique described by Ribeiro [16]. Total collagen was determined, after acid hydrolysis [10], by spectrophotometric dosage of L-hydroxyproline, using a conversion coefficient of L-hydroxyproline into collagen of 7.25 [8]. Soluble collagen was determined by the same method, after solubilisation for 30 minutes in a sodium phosphate buffer $(\mathrm{pH} 7)$ at $72-74{ }^{\circ} \mathrm{C}$. L-hydroxyproline content was converted into soluble collagen using a coefficient of 7.52 [7]. Intramuscular fat was determined according to the method of Marmer and Maxwell (1981, cit. [12]).

\subsection{Sensory analysis}

A skilled panel [1] was used for sensory analysis of 10 groups of samples (five for each breed). Three muscle samples of the same breed were assessed simultaneously, each of which corresponded to a different slaughter weight (weaning, 25 and $35 \mathrm{~kg}$ ). Panellists were asked to rate meat tenderness, juiciness and flavour, using a structured scale of ten points for each of the sensory traits $(0$ - very tough, very dry or very weak; 10 - very tender; very juicy or very intense). Frozen joints were thawed for $18 \mathrm{~h}$ at room temperature and then cooked in an electric oven until the meat internal temperature reached $70{ }^{\circ} \mathrm{C} \pm 5$ [1]. The LT muscles were then isolated, cut into $10 \mathrm{~mm}-$ thick slices and the samples were compared three at a time, one for each carcass weight, and served hot to each member of the panel.

\subsection{Statistical analysis}

Data were analysed using the GLM procedure of SAS [21]. Average daily weight gains (ADG) were determined for each lamb by linear regression. For ADG, two periods were considered: between weaning and $25 \mathrm{~kg}$ (ADG1) and between 25 and $35 \mathrm{~kg}$ (ADG2). Average daily weight gain was subjected to one-way analysis of variance, including the effect of breed. 
Table I. Means ( \pm standard deviation) of trial days (TD), live slaughter weight (LSW) and hot carcass weight $(\mathrm{HCW})$ of Serra da Estrela (SE) and Merino Branco (MB) lambs slaughtered at weaning, $25 \mathrm{~kg}$ and $35 \mathrm{~kg}$.

\begin{tabular}{|c|c|c|c|c|}
\hline & & $\mathrm{TD}$ & LSW (kg) & HCW (kg) \\
\hline \multirow[t]{3}{*}{ SE } & weaning & & $16.1 \pm 0.70$ & $7.9 \pm 0.36$ \\
\hline & 25 & $48.0 \pm 18.9$ & $25.5 \pm 0.88$ & $10.6 \pm 0.56$ \\
\hline & 35 & $84.7 \pm 18.08$ & $35.8 \pm 1.08$ & $15.7 \pm 0.56$ \\
\hline \multirow[t]{3}{*}{ MB } & weaning & & $16.3 \pm 0.40$ & $8.1 \pm 0.36$ \\
\hline & 25 & $22.3 \pm 8.43$ & $24.8 \pm 0.83$ & $10.6 \pm 0.83$ \\
\hline & 35 & $72.8 \pm 11.77$ & $36.5 \pm 1.12$ & $16.4 \pm 0.61$ \\
\hline
\end{tabular}

Carcass and meat traits (sensory traits excluded) were studied in order to evaluate the effects of breed and weight at slaughter and their interactions. The model included breed as a fixed effect and the linear or quadratic effect of HCW as a covariate. The purpose of this model was to study how the increase in HCW influenced the different traits studied, and whether this effect was similar in both breeds. The effect of the covariate was included only when significant $(P<0.05)$. A single regression coefficient was used for both breeds when interactions were not significant; otherwise, coefficients specific for each breed were used.

Least squares means for the different variables analysed were estimated for each breed, either directly (when the quadratic effect of carcass weight was not significant) or indirectly, with the Estimate statement in SAS, giving the least squares means at the appropriate levels of the covariate, i.e. mean and mean squared, with the regression coefficients estimated in the analysis of covariance. When appropriate, the expected values at weaning, $25 \mathrm{~kg}$ and $35 \mathrm{~kg}$, were obtained from regression equations, estimated as described above.

Sensory traits were studied by analysis of variance, with a model that included the effects of breed, slaughter weight and assessor. As the two breeds were not compared on the basis of the same session-day combination, these two effects are confounded. Therefore, breed as well as assessor were included in the linear model only as a way of removing these sources of variation.

\section{RESULTS}

The means obtained for trial days, live slaughter weight and hot carcass weight of lambs used in this study are presented in Table I. The groups of lambs slaughtered at weaning, at $25 \mathrm{~kg}$ and at $35 \mathrm{~kg} \mathrm{LW}$ will be referred to throughout the text as 16, 25 and 35 , respectively.

\subsection{Breed effect}

Growth rates of lambs are shown in Table II. MB lambs grew faster $(P<0.05)$

Table II. Mean average daily gain between 16 (weaning) and $25 \mathrm{~kg}$ live weight (ADG1) and between 25 and $35 \mathrm{~kg}$ live weight (ADG2) of Serra da Estrela (SE) and Merino Branco (MB) lambs.

\begin{tabular}{llll}
\hline & SE & MB & s.e. \\
\hline ADG1 (g) & $219.8^{\mathrm{a}}$ & $291.1^{\mathrm{b}}$ & 1.79 \\
ADG2 (g) & 269.0 & 294.0 & 9.02 \\
\hline
\end{tabular}

s.e.: standard error; means in the same row with different superscripts are different $(P<0.05)$. 
than SE lambs between weaning and $25 \mathrm{~kg}$ (ADG1); however, the difference in the 25 to $35 \mathrm{~kg}$ range (ADG2) was not significant.

Breed effect was significant for all carcass traits except dressing percentage (DP) (Tab. III). Concerning meat quality traits (Tab. IV), breed effect was only significant for water-holding capacity and the MB lambs showed a higher value than SE lambs.

\subsection{Weight effect}

The effect of HCW was significant for all carcass traits (Tab. III). All variables showed linear relationships with HCW, except for DP that had a quadratic relationship with the covariate. The effect of HCW was only different in both breeds for bone and total separable fat.

The effect of HCW was significant for all variables of meat quality traits of LT muscle except collagen content and collagen solubility (Tab. IV). Carcass weight showed linear relationships with intramuscular fat and water-holding capacity, and quadratic relationships with $\mathrm{pH}$ and temperature. Considering linear and quadratic regression coefficients of meat quality traits on HCW the linear effect of HCW was only different $(P<0.05)$ in both breeds for the temperature at $1 \mathrm{~h}$ after slaughter (T1).

The results of sensory analysis are presented in Table V. The effect of HCW on tenderness and flavour was not significant. However, juiciness was slightly higher for heavier carcasses $(P<0.01)$.

\section{DISCUSSION}

Growth rates were high but below the genetic potentials of the breeds [18]. In both weight intervals, the MB lambs, with higher growth rates and a lower age at slaughter, performed better than SE lambs. However, differences were only significant for ADG1, apparently due to larger numbers (ADG1 24 lambs; ADG2 - 12 lambs).
Dressing percentage was influenced by HCW (Tab. III). In both breeds, DP decreased $(P<0.05)$ between weaning (8 kg HCW) and $25 \mathrm{~kg} \mathrm{LW} \mathrm{(10.5} \mathrm{kg} \mathrm{HCW)}$ and presented a small, and not significant, variation between 25 and $35 \mathrm{~kg} \mathrm{LW} \mathrm{(16} \mathrm{kg}$ $\mathrm{HCW}$ ). This was mainly due to the rapid weight increase of gastric compartments and intestines which resulted from lamb weaning and the consequent increase in solid feed intake (results not shown). Although an increase in DP between 25 and $35 \mathrm{~kg}$ slaughter weight was expected [28], this did not happen probably because the slaughter weight range was too small.

For the same HCW, MB lambs had a higher muscle proportion than SE lambs (Tab. III), suggesting that the former were less mature $[13,27]$. However, the results obtained for carcass total separable fat (SF) do not support this conclusion. At weaning and at $25 \mathrm{~kg}$ slaughter weight, SE lambs had, respectively, 5.1 and 3.8 percentage points more SF than MB lambs $(P<0.05)$, but the values for $35 \mathrm{~kg} \mathrm{LW}$ were similar $(P>0.05)$ in both breeds. The differences between breeds in pre-weaning feeding management could possibly explain the higher proportion of fat observed in SE lambs for lower slaughter weights.

Serra da Estrela lambs had a higher proportion of KKCF than MB lambs. These results are in agreement with Wood et al. [27] and Butler-Hogg [4] that showed that in sheep, fat partitioning is related to breed type (dairy or meat). However, the effect of HCW on KKCF was similar in both breeds (Tab. III), which suggests that the greater $\mathrm{KKCF}$ deposition in the SE breed occurred before weaning.

Serra da Estrela lambs had a higher $(P<0.01)$ muscle/bone $(\mathrm{M} / \mathrm{B})$ ratio than the MB breed (Tab. III). Muscle/bone ratio is fairly independent of nutritional factors [5] and the higher $\mathrm{M} / \mathrm{B}$ ratio of the SE breed was also found when carcass composition was adjusted to the same subcutaneous fat proportion [23]. Simões and Mendes [24] 
Table III. Analysis of variance and least squares means (LSM) of dressing percentage (DP), muscle (M), bone (B), total separable fat (SF), kidney and knob channel fat $(\mathrm{KKCF})$, muscle/bone ratio $(\mathrm{M} / \mathrm{B})$ of lamb carcasses from two breeds at three slaughter weights.

\begin{tabular}{|c|c|c|c|c|c|c|c|c|c|c|c|c|}
\hline & \multicolumn{3}{|c|}{ Breed } & \multicolumn{4}{|c|}{ Weight } & & & & & \\
\hline & \multicolumn{3}{|c|}{$\operatorname{LSM}^{1}$} & \multicolumn{4}{|c|}{$\mathrm{LSM} \pm$ s.e. } & \multicolumn{5}{|c|}{ Significance of the effects } \\
\hline & SE & MB & s.e. & & 16 & 25 & 35 & $\mathrm{~B}$ & $\mathrm{HCW}$ & $\mathrm{HCW}$ & $3 * \mathrm{HC}$ & $\mathrm{B} * \mathrm{HCW}^{2}$ \\
\hline $\mathrm{DP}(\%)$ & 51.76 & 52.60 & 0.66 & & $55.2 \pm 0.66^{\mathrm{b}}$ & $52.8 \pm 0.58^{\mathrm{a}}$ & $52.5 \pm 0.60^{\mathrm{a}}$ & NS & $*$ & $*$ & NS & NS \\
\hline $\mathrm{M}(\%)$ & 59.45 & 61.06 & 0.49 & & $61.8 \pm 0.51^{\mathrm{c}}$ & $60.8 \pm 0.37^{b}$ & $58.5 \pm 0.55^{\mathrm{a}}$ & $*$ & $* *$ & NS & NS & NS \\
\hline $\mathrm{B}(\%)$ & 21.08 & 23.53 & 0.28 & $\begin{array}{l}\text { SE } \\
\text { MB }\end{array}$ & $\begin{array}{l}22.9 \pm 0.42^{\mathrm{c}} \\
26.5 \pm 0.43^{\mathrm{c}}\end{array}$ & $\begin{array}{l}21.7 \pm 0.30^{b} \\
21.7 \pm 0.31^{b}\end{array}$ & $\begin{array}{c}19.0 \pm 0.48^{\mathrm{a}} \\
20.1 \pm 0.44^{\mathrm{a}}\end{array}$ & $* *$ & $* *$ & NS & $* *$ & NS \\
\hline $\mathrm{SF}(\%)$ & 17.11 & 13.96 & 0.57 & $\begin{array}{l}\text { SE } \\
\text { MB }\end{array}$ & $\begin{array}{r}14.7 \pm 0.85^{\mathrm{a}} \\
9.6 \pm 0.86^{\mathrm{a}}\end{array}$ & $\begin{array}{l}16.3 \pm 0.60^{b} \\
12.5 \pm 0.62^{b}\end{array}$ & $\begin{array}{l}19.9 \pm 0.96^{\mathrm{c}} \\
18.9 \pm 0.88^{\mathrm{c}}\end{array}$ & $* *$ & $* *$ & NS & $* *$ & NS \\
\hline $\operatorname{KKCF}(\%)$ & 2.35 & 1.43 & 0.10 & & $1.36 \pm 0.11^{\mathrm{a}}$ & $1.71 \pm 0.08^{b}$ & $2.48 \pm 0.12^{\mathrm{c}}$ & $* *$ & $* *$ & NS & NS & NS \\
\hline $\mathrm{M} / \mathrm{B}$ & 2.84 & 2.63 & 0.03 & & $2.50 \pm 0.03^{\mathrm{a}}$ & $2.66 \pm 0.02^{\mathrm{b}}$ & $3.00 \pm 0.04^{\mathrm{c}}$ & $* *$ & $* *$ & NS & NS & NS \\
\hline
\end{tabular}

${ }^{1}$ Values adjusted to the same hot carcass weight (11.8 kg); B: breed; HCW: hot carcass weight; SE: Serra da Estrela; MB: Merino Branco; s.e.: standard error; NS: not significant; $* P<0.05 ; * * P<0.01$; means in the same row with different superscripts are different $(P<0.05)$. 
Table IV. Analysis of variance and least squares means (LSM) of total collagen (TC), collagen solubility (CS), intramuscular fat (IMF), water holding capacity (WHC), $\mathrm{pH}$ at 1, 3 and $24 \mathrm{~h}$ after slaughter and temperature (T) of lamb muscle at 1 and $3 \mathrm{~h}$ after slaughter from two breeds at three slaughter weights.

\begin{tabular}{|c|c|c|c|c|c|c|c|c|c|c|c|c|}
\hline & \multicolumn{3}{|c|}{ Breed } & \multicolumn{4}{|c|}{ Weight } & & & & & \\
\hline & \multicolumn{3}{|c|}{$\mathrm{LSM}^{1}$} & \multicolumn{4}{|c|}{$\mathrm{LSM} \pm$ s.e. } & \multicolumn{5}{|c|}{ Significance of the effects } \\
\hline & SE & MB & s.e. & & 16 & 25 & 35 & B & $\mathrm{HCW}$ & $\mathrm{HCW}^{2}$ & $\mathrm{~B} * \mathrm{HCW}$ & $\mathrm{B} * \mathrm{HCW}^{2}$ \\
\hline $\mathrm{TC}(\% \mathrm{DM})$ & 2.19 & 2.42 & 0.16 & & & & & NS & NS & NS & NS & NS \\
\hline CS $(\%)$ & 28.6 & 24.4 & 1.63 & & & & & NS & NS & NS & NS & NS \\
\hline $\operatorname{IMF}(\%)$ & 3.04 & 2.79 & 0.11 & & $2.72 \pm 0.12^{\mathrm{a}}$ & $2.85 \pm 0.08^{\mathrm{b}}$ & $3.14 \pm 0.12^{\mathrm{c}}$ & NS & $*$ & NS & NS & NS \\
\hline WHC (\%) & 33.4 & 27.5 & 1.03 & & $25.6 \pm 1.09^{\mathrm{a}}$ & $28.8 \pm 0.78^{b}$ & $35.9 \pm 1.17^{\mathrm{c}}$ & $* *$ & $* *$ & NS & NS & NS \\
\hline $\mathrm{pH}(1)$ & 6.32 & 6.23 & 0.07 & & $6.72 \pm 0.06^{\mathrm{b}}$ & $6.37 \pm 0.05^{\mathrm{a}}$ & $6.35 \pm 0.05^{\mathrm{a}}$ & NS & $* *$ & $* *$ & NS & NS \\
\hline $\mathrm{pH}(3)$ & 5.92 & 5.88 & 0.05 & & $6.21 \pm 0.04^{c}$ & $5.98 \pm 0.04^{\mathrm{b}}$ & $5.85 \pm 0.04^{\mathrm{a}}$ & NS & $* *$ & $*$ & NS & NS \\
\hline pH (24) & 5.51 & 5.55 & 0.05 & & $5.74 \pm 0.04^{b}$ & $5.59 \pm 0.03^{\mathrm{a}}$ & $5.56 \pm 0.03^{\mathrm{a}}$ & NS & $* *$ & $*$ & NS & NS \\
\hline $\mathrm{T}(1)\left({ }^{\circ} \mathrm{C}\right)$ & 32.2 & 30.6 & 0.70 & $\begin{array}{l}\text { SE } \\
\text { MB }\end{array}$ & $\begin{array}{l}26.4 \pm 0.63^{\mathrm{a}} \\
27.6 \pm 0.67^{\mathrm{a}}\end{array}$ & $\begin{array}{l}30.7 \pm 0.59^{b} \\
29.8 \pm 0.58^{b}\end{array}$ & $\begin{array}{l}33.5 \pm 0.67^{c} \\
31.6 \pm 0.57^{c}\end{array}$ & NS & $* *$ & $* *$ & $* *$ & $* *$ \\
\hline $\mathrm{T}(3)\left({ }^{\circ} \mathrm{C}\right)$ & 22.5 & 23.1 & 0.48 & & $16.7 \pm 0.40^{\mathrm{a}}$ & $21.6 \pm 0.36^{\mathrm{b}}$ & $24.9 \pm 0.37^{c}$ & NS & $* *$ & $* *$ & NS & NS \\
\hline
\end{tabular}

B: breed; HCW: hot carcass weight; SE: Serra da Estrela; MB: Merino Branco; s.e: standard error; DM: dry matter; NS: not significant; $* P<0.05 ; * * P<0.01 ;{ }^{1}$ values adjusted to the same HCW $(11.8 \mathrm{~kg})$, except total collagen and collagen solubility; means in the same row with different superscripts are different $(P<0.05)$. 
Table V. Least squares means of tenderness, juiciness and flavour of Longissimus thoracis muscle of lambs at three slaughter stages.

\begin{tabular}{lllllc}
\hline & \multicolumn{3}{c}{ Slaughter weight $(\mathrm{kg})$} & \multirow{2}{*}{ Effect significance } \\
\cline { 2 - 5 } & 16 & 25 & 35 & s.e. & \\
\hline Tenderness & 6.78 & 7.14 & 6.93 & 0.15 & NS \\
Juiciness & $5.57^{\mathrm{a}}$ & $6.16^{\mathrm{b}}$ & $6.25^{\mathrm{b}}$ & 0.16 & $*$ \\
Flavour & 4.46 & 4.54 & 4.71 & 0.15 & NS \\
\hline
\end{tabular}

s.e: standard error; NS: not significant; $* P<0.05$; means in the same row with different superscripts are different $(P<0.05)$.

evaluated the bone density of these breeds and found lower $(P<0.05)$ values for SE $\left(1.32 \mathrm{vs} .1 .39 \mathrm{~g} \cdot \mathrm{cm}^{-2}\right)$. This difference may partially explain the higher $\mathrm{M} / \mathrm{B}$ ratio of the SE breed.

Increasing $\mathrm{HCW}$, muscle and bone carcass proportions decreased and fat increased (Tab. III), which is the standard lamb growth pattern, already described in the literature $[4,11,27]$. As observed by Bailey et al. [2] and Zupka et al. [30], the M/B ratio increased with slaughter weight, which can be explained by the differences in the growth patterns of these tissues [4, 11, 27]. At weaning, both breeds showed $\mathrm{M} / \mathrm{B}$ values close to 2.5 , and for $35 \mathrm{~kg} \mathrm{LW}$ the values obtained for the two breeds were about 3.0.

Tenderness is one of the major organoleptic characteristics of red meats and the concentration and heat solubility of intramuscular collagen, among others, may influence this. The concentration of collagen varies little during the lifetime of the animal but its solubility decreases [29], due to the increase of multivalent and nonreducible cross-links between collagen molecules [3]. The decrease of collagen solubility has long been associated with a decrease in meat tenderness with age [6]. In the weight range studied, collagen solubility was not affected by HCW (Tab. IV), which probably results from using light lambs, slaughtered up until 140 days of age. The results obtained for muscle collagen agree with those of sensory analysis, showing that meat tenderness was not affected by slaughter weight (Tab. V), and suggest that the contribution of connective tissue to tenderness variation of $\mathrm{LL}$ and LT muscles from young lambs, is rather small. This agrees with the conclusion of Shorthose and Harris [22] on beef, that is, that the effect of age on muscular adhesion (which is related to connective tissue effects) is minimal for muscles with a low collagen content (Psoas, Longissimus dorsi and Gluteus medius).

Values for intramuscular fat (IMF) content in LT were lower than $5 \%$ of muscle fresh weight, that is, they correspond to those of lean meat (Tab. IV). According to Wood [26], 2-3\% of IMF is needed to ensure the organoleptic qualities of meat. Even in the case of lambs slaughtered at weaning, which presented very lean carcasses, IMF was above $2 \%$ (2.85 \pm 0.14 , $\mathrm{SE} ; 2.59 \pm 0.14, \mathrm{MB})$. Intramuscular fat content increased $(P<0.05)$ with HCW but at a slower rate than SF or KKCF. Intramuscular fat is generally considered as the most late-growing carcass fat depot. These results suggest that in both breeds, the phase of fastest rate of intramuscular fat deposition occurs at higher weights.

Water-holding capacity (WHC) influences meat sensory qualities, namely juiciness and tenderness. This was the only meat quality trait that was different $(P<0.05)$ between breeds, being higher for MB lambs (Tab. IV). It decreased when HCW increased, which agrees with the results of Sañudo 
et al. [19] that compared lamb carcasses of $10 \mathrm{~kg}$ and $19 \mathrm{~kg}$. However, Sañudo et al. [20] found no difference in WHC in the LT muscle of lambs when carcass weight increased from 8 to $13 \mathrm{~kg}$.

The WHC of meat depends mainly on the final $\mathrm{pH}$ and on the rates of muscle $\mathrm{pH}$ and temperature decline during the development of rigor mortis [15, 17]. Pearson and Young [15] and More O'Ferral [14] considered that a small increase in final $\mathrm{pH}$ from 5.5 to 6.5 has a considerable positive effect on the WHC of meat. Thus, the variation in WHC may be related to the effect of HCW values on $\mathrm{pH} 24 \mathrm{~h}$ after slaughter, which was higher for lighter carcasses (5.74 vs. 5.59 and 5.56). We also found a negative correlation $(-0.53, P<0.01)$ between WHC and $\mathrm{pH} 3 \mathrm{~h}$ after slaughter, which agrees with More O'Ferrall et al. [14], and suggests that higher rates of $\mathrm{pH}$ decline during the onset of rigor mortis may be related to lower values of muscle WHC.

The results of sensory analysis did not show any significant difference in the sensory scores of the LT of lambs slaughtered at weaning, 25 or $35 \mathrm{~kg} \mathrm{LW}$ (Tab. V), except for juiciness, that was slightly lower for lighter carcasses. The same results were obtained by Sañudo et al. [20] in Rasa Aragonesa lambs slaughtered between 8 and $13 \mathrm{~kg}$ carcass weight. In view of the effect of weight on WHC, we could expect an opposite effect on juiciness. However, the higher IMF content of meat from heavier carcasses probably explains these results.

Nevertheless, our data show that in the weight range studied, an increase in slaughter weight had no negative effects on meat sensory traits, and that SE and MB lambs may be slaughtered at higher weights than those normally slaughtered.

\section{CONCLUSIONS}

Serra da Estrela and Merino Branco lambs fattened with a diet of dehydrated lucerne showed acceptable growth rates and produced carcasses with adequate levels of fat.

The changes in meat quality do not allow the recommendation of a particular slaughter weight between weaning and $35 \mathrm{~kg} \mathrm{LW}$ for the breeds studied. Thus slaughter weight could be determined according to the desired carcass composition, to maximise the muscle/bone ratio without producing excessive fat, always taking into account consumer demands. These results show that it is possible to slaughter these breeds within a large range of weights, thus making the current production systems more adaptable to seasonal variations in price on the lamb market.

\section{ACKNOWLEDGEMENTS}

The authors would like to thank Luis Gama for his help in the statistical analysis, the abattoir staff, particularly Paula Ferreira, for carcass and meat quality determination, and Ann Barreiro and Lúcia Rato for the translation.

\section{REFERENCES}

[1] AMSA, Guidelines for cookery and sensory evaluation of meat, American Meat Science Association, Chicago, USA, 1978.

[2] Bailey C.M., Liboriussen T., Andersen H.R., Andersen B.B., Producing beef from intact male progeny of holstein sires: feed efficiency and compositional characters, J. Anim. Sci. 61 (1985) 27-35.

[3] Bailey A., Connective tissue and meat quality, in: Proc. 34th Intern. Cong. of Meat Sci. and Techn., Brisbane, 1988, pp. 152-160.

[4] Butler-Hogg B.W., The growth of Clun and Southdown sheep: body composition and the partitioning of total body fat, Anim. Prod. 39 (1984) 405-411.

[5] Butler-Hogg B.W, Johnsson I.D., Fat partitioning and tissue distribution in crossbred ewes following different growth paths, Anim. Prod. 42 (1986) 65-72.

[6] Cross H.R., Smith G.C., Carpenter Z.L., Palatability of individual muscles from ovine leg steaks as related to chemical and histological traits, J. Food Sci. 37 (1972) 282-285. 
[7] Cross H.R., Carpenter Z.L., Smith G.C., Effects of intramuscular collagen and elastin on bovine muscle tenderness, J. Food Sci. 38 (1973 998-1003.

[8] Goll D.E., Bray R.W., Hoekstra W.G., Age associated changes in muscle composition. The isolation and properties of collagenous residue from bovine muscle, J. Food Sci. 28 (1963) 503-509.

[9] ISO-International Organisation for Standardisation, Determination of moisture content in meat and meat products, ISO 1442, 1973.

[10] ISO-International Organisation for Standardisation, Meat and meat products: Part II. Determination of L-hydroxyproline content, ISO 3 , 1978.

[11] Mahgoub O., Lodge G.A., Growth and body composition of Omani local sheep. 1. Live weight growth and carcass and non-carcass characteristics, Anim. Prod. 58 (1994) 365-372.

[12] Maxwell R.J., Determination of total lipid and lipid subclasses in meat and meat products, J. Assoc. Off. Anal. Chem. 70 (1987) 74-79.

[13] McClelland T.H., Bonaiti B., Taylor St. C.S., Breed differences in body composition of equally mature sheep, Anim. Prod. 23 (1976) 281-293.

[14] More O'Ferrall G.J., Joseph R.L., Tarrant P.V., McGloughin P., Phenotypic and genetic parameters of carcass and meat quality traits in cattle, Livest. Prod. Sci. 21 (1989) 35-47.

[15] Pearson A.M., Young R.B., Muscle and Meat Biochemistry, in: Schweigert B.S., Taylor S.L. (Eds.), Food Science and Technology - A series of monographs, Academic Press, Inc., San Diego, 1989.

[16] Ribeiro M.F.S.P.F., Influência do genótipo e do stress na qualidade da carcaça e da carne de suíno, Tese de Mestrado, Instituto Superior de Agronomia, U.T.L., Lisboa, Portugal, 1992.

[17] Roseiro L.C., Santos C., Melo R.S., Muscle pH60, colour ( L, a, b) and water-holding capacity and the influence of post mortem muscle temperature, Meat Sci. 38 (1994) 353-359.

[18] Santos-Silva J., Portugal A.V., Influência do peso da carcaça na qualidade das carcaças de borregos das raças Serra da Estrela e Merino Branco produzidos em sistemas intensivos de produção, Rev. Port. Zootecnia, ano VII, ${ }^{\circ} 1$ (2000) 109-128.
[19] Sañudo C., Sierra I., Estudio de la calidad de la canal y de la carne en animales cruzados Romanov por Rasa Aragonesa. I - Descripcion y comparacion entre los tipos de ternasco y pascual, An. Fac. Vet. 16-17 (1981-1982) 285-295.

[20] Sañudo C., Santolaria M.P., Maria G., Osorio M., Sierra I., Influence of carcass weight on instrumental and sensory lamb meat quality in intensive production systems, Meat Sci. 42 (1996) 195-202.

[21] SAS, SAS/STAT User's Guide (Release 6.03), SAS Inst., Cary, NC, USA, 1988.

[22] Shorthose W.R., Harris P.V., Effect of animal age on the tenderness of selected beef muscles, J. Food Sci. 55 (1990) 1-8.

[23] Simões J.A., Tissue distribution and partition in Portuguese sheep and sheep crosses, Rev. Port. Ciências Veterinárias, Vol. LXXXVII, 504 (1992) 190-194.

[24] Simões J.A., Mendes I., Relationship between conformation and muscle/bone ratio among several sheep breeds, Vet. Técnica. Fev (2000) 24-25.

[25] Solomon M.B., Kemp J.D., Moody W.G., Ely D.G., Fox J.D., Effect of breed and slaughter weight on physical, chemical and organoleptic properties of lamb carcasses, J. Anim. Sci. 51 (1980) 1102-1107.

[26] Wood J.D., Consequences for meat quality of reducing carcass fatness, in: Wood J.D., Fisher A.V. (Eds.), Reducing fatness in meat animals, Elsevier Applied Sci., London, UK, 1990, pp. 344-397.

[27] Wood J.D., MacFie J.H., Pomeroy R.W., Twinn D.J., Carcass composition in four sheep breeds the importance of type of breed and stage of maturity, Anim. Prod. 30 (1980) 135-152.

[28] Wood J.D., MacFie H.J.H., Brown A.J., Effects of body weight, breed and sex on killing-out percentage and non-carcass component weights in lambs, Meat Sci. 9 (1983) 89-99.

[29] Young O.A., Braggins T.J., Tenderness of ovine Semimembranosus: is collagen concentration or solubility the critical factor?, Meat Sci. 35 (1993) 213-221.

[30] Zupka Z., Jelinek P., Subrt J., Allometric analysis of ram growth in the postnatal period, Zivocisna Vyroba 41 (1996) 387-390.

To access this journal online: www.edpsciences.org 